\title{
Olivine Weathering against Climate Change
}

\author{
Roelof Dirk Schuiling \\ Faculty of Geosciences, Utrecht University, Utrecht, Netherlands \\ Email: schuiling@geo.uu.nl
}

How to cite this paper: Schuiling, R.D. (2017) Olivine Weathering against Climate Change. Natural Science, 9, 21-26. http://dx.doi.org/10.4236/ns.2017.91002

Received: June 23, 2016

Accepted: January 14, 2017

Published: January 17, 2017

Copyright (c) 2017 by author and Scientific Research Publishing Inc. This work is licensed under the Creative Commons Attribution International License (CC BY 4.0).

http://creativecommons.org/licenses/by/4.0/

\begin{abstract}
One natural process has since the origin of the Earth removed almost all the $\mathrm{CO}_{2}$ that was ever produced by volcanism. That process is the reaction of $\mathrm{CO}_{2}$ and water with rocks, a process known as weathering. It is a logical choice to see if we can use the same process to remove also the vastly higher $\mathrm{CO}_{2}$ emissions caused by burning in a few hundred years the fossil fuels that have taken hundreds of millions of years for their formation. Many people claim that the rate of weathering of olivine is too slow to counter climate change, but they base this on experimental data in sterile laboratories, under exclusion of biotic and other environmental factors. As many conditions determine the weathering rate at each specific location, these laboratory conditions are irrelevant for the real world. Weathering models based on these laboratory data are off by orders of magnitude. Weathering experiments that use conditions closer to nature [1] show already much higher weathering rates. In this note I provide some data on the weathering of olivine in nature, which make clear that the weathering of olivine is fast enough to play an important role in the cycle of $\mathrm{CO}_{2}$ capture and its safe and sustainable storage as carbonate rocks. The $\mathrm{CO}_{2}$ released by volcanism has always been captured by the weathering of rocks since the origin of the Earth. Without this mechanism the Earth would be a lifeless planet with a $\mathrm{CO}_{2}$ atmosphere in the order of 100 bar, as our neighbor planet Venus demonstrates.
\end{abstract}

\section{Keywords}

Climatic Change, Olivine, Rate of Weathering, Biotic Effects

\section{Introduction}

The Eifel volcanism provided the first clue for the author that weathering in nature proceeds considerably faster than in the laboratory. As soon as the Eifel volcanism began, contemporaneous Rhine sediments at the Dutch border suddenly started to contain plenty of volcanic minerals like augite and basaltic hornblende. Strangely enough, although olivine is one of the commonest minerals 
in the Eifel volcanics, these sediments contained no olivine. Apparently, all the olivine grains had completely disappeared by weathering on the short trip along the Rhine from Bonn to the Dutch border, around $150 \mathrm{~km}$. Although evidently much faster than weathering rates obtained in laboratory studies, unfortunately it is difficult to derive hard data for the rate of weathering of olivine from this evidence.

From studies of weathering of large dunite massifs in tropical countries it is possible to derive realistic weathering rates of olivine over long geological times. A first example comes from the Kaloum peninsula near Conakry, Guinea, West Africa. The backbone of this $50 \mathrm{~km}$ long peninsula is formed by a vertical intrusion of a dunite plate, with a cross-section of approximately $5 \mathrm{~km}$ (Figure 1). The rock is completely covered by its thick lateritic weathering crust, which makes it stand out as a red body on a satellite image. Although I have crisscrossed the area a number of times, I have not seen a single outcrop of dunite. The only sample in my possession of this dunite is from a drill core, provided by the Geological Survey of Guinea.

Only some basic information on the dunite body is needed to calculate its average (minimum) weathering rate. The required data are its radiometric age, the average thickness of the weathering crust, and the composition of the laterite compared to the composition of the fresh rock [1], from which it was formed. During tropical weathering, essentially all the magnesium and silica were removed, leaving a lateritic crust mainly composed of iron (hydr-)oxides. As olivine is essentially a magnesium-silicate, this means that around $90 \%$ of the rock has vanished, so 1 meter of laterite is equivalent to 10 meters of fresh dunite. The thickness of the weathering crust is in the order of 100 meter, so during its existence at least $1 \mathrm{~km}$ of dunite has weathered, and even more if some of the laterite had been eroded in the meantime. As the radiometric age (the time it was emplaced) of the rock is 195 million years [2], its average weathering rate is 1000 meters $/ 195$ million years $=5.1 \mathrm{micron} /$ year. A similar number results from a

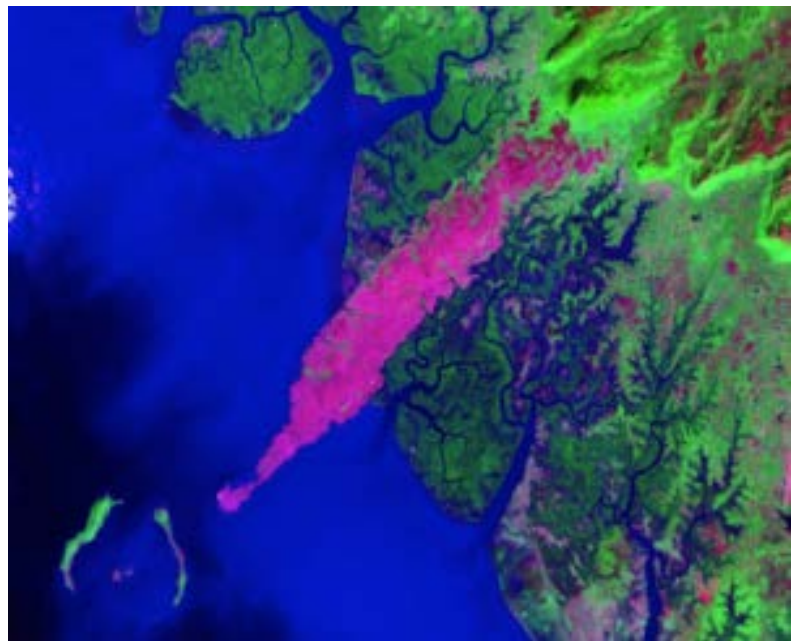

Figure 1. Satellite picture of the dunite of the Kaloum peninsula, Guinea, West-Africa the length of the (reddish) dunite body is appr. $50 \mathrm{~km}$. 
dunite massif at Jacupiranga/Brazil [3]. Due to the fact that there the thickness of the weathering crust is not exactly known, because the drill core stopped at 40 meter depth, still in lateritic weathering crust, the results are even less well constrained.

5.1 micron/year is already more than ten times faster than the weathering rates obtained in sterile laboratories, but is this the real rate of weathering of fresh olivine rock in nature, when exposed to tropical conditions? In fact, there are 3 factors that cause the real weathering rate of exposed rock to be even considerably larger. The first is the fact that the dunite body is an intrusion, which means that after its emplacement it took some time before it was exposed to the atmosphere, probably several tens of millions of years later. First its overburden had to be removed by erosion, before it could start to weather. This shortens the time available for weathering. The second consideration is the fact that the rate of weathering goes down as the thickness of the overlying lateritic weathering crust increases, because it will make the contact of the rock with the atmosphere increasingly difficult. It is likely that the real weathering rate would be around 20 to $30 \mathrm{micron} /$ year when the rock is exposed. This is the outcome for solid rock. The third consideration refers to the difference between the rate of weathering of solid rock and the rate of weathering of individual loose grains. If we spread olivine grains, they are attacked on all sides by weathering. This would make the rate of weathering of a grain 4 times more than its rate of weathering for a flat circle with the same radius. The outcome of these three factors is that under favorable conditions of wet tropics, weathering rates of olivine grains will be 50 micron/year or more.

From the above considerations, it should be clear that it is impossible and meaningless to give an exact number for the rate of weathering of olivine in the real world, but it is also clear that it is several orders of magnitude larger than what is observed in the laboratory under sterile conditions, using distilled water. As people have used the low number for olivine weathering observed in the laboratory to model its behavior in nature, many people were led to believe that olivine weathering is not fast enough to play a role in halting climate change. This is a deplorable misconception, because instead of adopting the cost-effective method of olivine weathering, much more expensive and unproven technologies are being developed to counteract climate change.

\section{Reasons for the Discrepancy}

Why is the rate of weathering of olivine in nature so vastly higher than rates determined in the laboratory? An obvious reason is that the laboratory experiments were carried out with distilled water. In natural waters the reaction goes faster, particularly if the waters are saline like sea water, and even much faster in brines, as we have observed in our weathering experiments (author's unpublished data). The main difference, however, are the biotic factors. Let me briefly note some of these, but it is likely that there are other, yet unknown factors, like the role of soil bacteria and earth worms. 
- Higher plants live in symbiosis with mycorrhizal fungi [4]. These excrete several organic acids, in which soil minerals quickly dissolve. The plants use the mineralized soil solutions to obtain their required mineral constituents. In return, the plants provide the fungi with sugars, which makes the symbiosis complete. It is recognized [5] that ectorrhizal fungi also play an important role in silicate weathering.

- Lichens excrete oxalic acid, which attacks the underlying rock [6].

- It was found that the weathering of minerals went considerably faster near ant hills or termite hills [7].

- Tidal flats are densely populated by lugworms. The upper few centimeters pass on average three times a year through their guts. Experiments have shown that pieces of basalt weathered fast during digestion, and were returned as small heaps of clay [8] [9]. It is likely that this will also hold for olivine, when olivine grains are spread over tidal flats [10].

Another, non-biotic but very important reason for rapid weathering is motion. In rivers, or on beaches in the surf, or in shallow waters with strong bottom currents, olivine grains are worn down by collision and abrasion. Slivers with sizes around a micron are knocked off. We found in our very modest imitation of a surf, by moving olivine grains slowly along the bottom of an erlenmeyer, that these slivers weathered extremely fast, in the order of days [11]. A second reason of fast weathering caused by motion is that olivine grains in a fixed position often develop a silica-rich rim which slows down further weathering. When the grains are moving, this rim is rapidly scratched off.

\section{Implications for Climate Change}

It is a logical choice to look at the process of enhanced weathering to counteract climate change, because weathering is the only process that has captured huge volumes of $\mathrm{CO}_{2}$ during the whole history of the Earth. Weathering produces bicarbonate solutions that are carried by rivers to the sea, where corals, shellfish and plankton turn them into carbonate rocks (limestones and dolomites). These rocks contain approximately a million times more $\mathrm{CO}_{2}$ than the oceans, the atmosphere and the biosphere together. They are the safe and sustainable storage rooms for $\mathrm{CO}_{2}$. This process has removed almost completely all the $\mathrm{CO}_{2}$ that was ever produced by volcanoes, and thus provided the conditions for a livable planet. In the present situation we need to enhance this weathering process to make up for the vastly higher emission of $\mathrm{CO}_{2}$ caused by our burning of fossil fuels. The choice of olivine, or its hydrated relative serpentine, to enhance weathering is logical, because both minerals are very abundant, and both weather fast. To make the spreading of these minerals even more effective to capture $\mathrm{CO}_{2}$, one should select environments that increase their weathering rates. Among these a lush vegetation and a high-energy fluviatile or marine environment are the most effective. Mining olivine rocks, milling them, and spreading the grains over these environments is probably the most effective, safe and low-cost way to counter climate change and the accompanying ocean acidification. Olivine can be used 
in many applications, from phytomining of nickel to increasing the productivity of rice culture, and from culturing diatoms for biofuel production to quenching forest fires with serpentine slurries, or improving the internal atmosphere of offices or schools that suffer from the sick-building syndrome [12]. We make use of processes that have shown to be effective over the whole history of the Earth, and it is highly unlikely that these processes will all of a sudden produce negative effects, when we apply them in the geotherapy of our Earth.

\section{Conclusion}

There is no such thing as the rate of weathering of olivine. What nature tells us is that the weathering of olivine in nature presents several orders of magnitude faster than those shown by experiments in sterile laboratories. Olivine weathering can become the most effective and safest way to counter climate change in a cost-effective way [12].

\section{Acknowledgements}

I want to thank Prof. M. A. Elburg/Johannesburg, Prof. W. Visser/Oman, Prof. J. Bijma/Bremen and Prof. G. Koster van Groos/Chicago for their critical remarks.

\section{References}

[1] Franke, W.A. (2009) The Duarbility of Rocks-Developing a Test of Rock Resistance to Chemical Weathering. American Journal of Science, 309, 711-730.

[2] Golightly, J.P. (1981) Nickeliferous Laterite Deposits. Economic Geology 75th Anniversary Volume, 710-735.

[3] Oliveira, S.M.B., Melfi, A.J., Carvalho, A., Friedrich, G., Marker, A. and Kanig, M. (1988) Lateritic Evolution of the Jacupiranga Complex, S.P. Geochimica Brasiliensis, 2, 119-126.

[4] Van Schöll, L., Kuyper, Th.W., Smits, M.M., Landeweert, R., Hoffland, E. and Van Bremen, N. (2008) Rock-Eating Mycorrhizas: Their Role in Plant Nutrition and Biogeochemical Cycles. Plant and Soil, 303, 35-47.

https://doi.org/10.1007/s11104-007-9513-0

[5] Quirk, J., Beerling, D.J., Banwart, S.A., Kakonyi, G., Roero-Gonzales, M.E. and Leake, J.R. (2012) Evolution of trees and Mycorrhizal Fugi Intensifies Silicate Weathering. Biology Letters, 8, 1006-1011. https://doi.org/10.1098/rsbl.2012.0503

[6] Williams, M.E. and Rudolph, E.D. (1974) The Role of Lichens and Associated Fungi in the Chemical Weathering of Rock. Mycologia, 66, 648-660. https://doi.org/10.2307/3758168

[7] Dorn, R.I. (2014) Ants as a Powerful Biotic Agent of Olivine and Plagioclase Dissolution. Geology. Data Repository item 2014278.

[8] Needham, S.J., Worden, S.H. and Cuadros, J. (2006) Sediment Ingestion by Worms and the Production of Bio-Clays: A Study of Macrobiologically Enhanced Weathering and Early Diagenetic Processes. Sedimentology, 53, 567-579.

https://doi.org/10.1111/j.1365-3091.2006.00781.x

[9] Worden, R.H., Needham, S.J. and Cuadros, J. (2006) The Worm Gut; A Natural Clay Mineral Factory and a Possible Cause of Diagenetic Grain Coats in Sandstones. Journal of Geochemical Exploration, 89, 428-431.

https://doi.org/10.1016/j.gexplo.2005.12.011 
[10] Montserrat, F., Hidalgo, S., Leermakers, M. and Meysman, F.J.R. (in prep.) Sediment Macrofauna Increases $\mathrm{CO}_{2}$ Sequestration through Enhanced Mineral Weathering.

[11] Schuiling, R.D. and de Boer, P.L. (2011) Rolling Stones; Fast Weathering of Olivine in Shallow Seas for Cost-Effective $\mathrm{CO}_{2}$ Capture and Mitigation of Global Warming and Ocean Acidification. Earth System Dynamics Discussions, 2, 551-568. https://doi.org/10.5194/esdd-2-551-2011

[12] Schuiling, R.D. and de Boer, P.L. (2013) Six Commercially Viable Ways to Remove $\mathrm{CO}_{2}$ from the Atmosphere and/or Reduce $\mathrm{CO}_{2}$ Emissions. Environmental Sciences Europe, 25, 35.

Submit or recommend next manuscript to SCIRP and we will provide best service for you:

Accepting pre-submission inquiries through Email, Facebook, LinkedIn, Twitter, etc. A wide selection of journals (inclusive of 9 subjects, more than 200 journals)

Providing 24-hour high-quality service

User-friendly online submission system

Fair and swift peer-review system

Efficient typesetting and proofreading procedure

Display of the result of downloads and visits, as well as the number of cited articles Maximum dissemination of your research work

Submit your manuscript at: http://papersubmission.scirp.org/

Or contact ns@scirp.org 